Sahel drought

\section{Call for joint action}

A CALL for the formation of a Sahel fund to combat the area's drought and desertification was issued last week at the end of the sixth meeting of the Permanent Interstate Committee for Drought Control in the Sahel (CILLS), at Niamey, the capital of Niger. The committee was formed ten years ago by eight West African governments (Cape Verde Islands, Chad, Gambia, Mali, Mauritania, Niger, Senegal and Upper Volta) to coordinate action during severe droughts. The sixth meeting was attended by heads of governments and the director-general of the Food and Agricultural Organization.

The World Meteorological Organization considers that the drought in Africa which began in 1968 has not yet ended, and is worst in the Sahel. Agencies working in the area report that although conditions in the Sahel are not everywhere as serious as in $1968-73$, drought is now locally severe in the north. For example, in Mauritania, 85 per cent of the basic cereal crop has failed, with the result that half the population is now gathered in the capital of Nouakchott. In northern Mali, all cereals are badly affected. In Upper Volta, millet has failed entirely and the sorghum crop is poor. So a return to the conditions of the 1970 s is feared. Ghana, with its third consecutive poor harvest and an increase of 10 per cent in population since the expulsion of Ghanaians from Nigeria, is expecting a fourfold increase in food prices within six months. In Senegal the cereal situation is disastrous, with animals dying and water holes drying up. But in the southern areas, harvests have been adequate and there are even some surpluses.

Water is the main problem. It is estimated that only 25-30 per cent of Sahelians have access to sufficient water. Desertification, which according to the United $\mathrm{Na}$ tions Environment Programme, consumes 1.5 million hectares of potentially productive land a year, is exacerbated by population growth ( 2.7 per cent a year) and overgrazing.

Wood consumption ( 90 per cent of it for burning) is also a worry, especially because attempts at reafforestation have not been encouraging. The area could show a substantial surplus if consumption were reduced by even one per cent.

The effects of physical problems are made worse by the chronic social and economic conditions of the region, including inadequate transport, low farm prices, which discourage the production of food, and a general insufficiency of money. Emergency aid is difficult to deliver.

According to the Club du Sahel, formed by the Organization for Economic Cooperation and Development and several West African governments and various

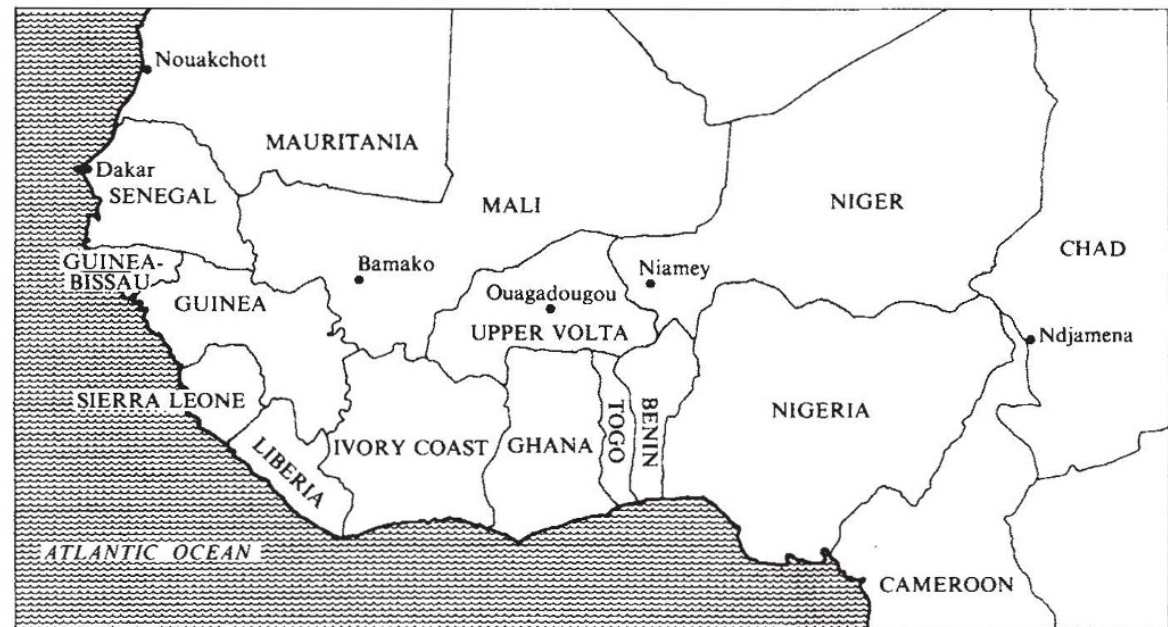

Countries affected by the drought in the Sahel region include Mauritania, Senegal, Mali, Upper Volta, Niger, Nigeria, Chad and Ghana.

development agencies, aid to the area has doubled in ten years and now amounts to 15 per cent of the total gross national product in the Sahel states and more than 20 per cent of the gross national product in half of them. So dependent on aid has the region become that some agencies now fear that long-term massive food aid is sapping the ability of the region to acquire the resources necessary to respond to normal climatic swings, let alone to cope with disaster. Oxfam, the British charity, agrees with the UK Overseas Development Administration that the best help is the swift delivery of emergency food aid followed by agricultural aid, such as the supply of seed corn, as conditions improve.

One novel possibility is that climatic change and crop yield may be predictable from satellite data (see p.528 for a study of satellite results); this would be especially valuable if there is a recurring pattern comparable with the 10-year cycle now established for Botswana. A British project is currently under consideration by the
Overseas Development Administration and the Food and Agricultural Organization. The World Meteorological Organization, however, considers that drought cannot be predicted and that there is no practical method of enhancing precipitation, but that much could be done to ameliorate the effects of droughts by improving agrometeorological monitoring services and the wide application of increased information on an interdisciplinary basis.

Conditions in the Sahel are part of a climatic threat to the world's poorest people. Nine Southern African states also made an emergency appeal last week. Oxfam, in common with other international agencies, has received more requests for help in the past six months than at any time in its entire 40-year history. Abnormal collapse of development across a whole sweep of countries so economically depressed that they cannot possibly cope themselves".

Sarah Tooze weather, Oxfam says, could lead to "the

\title{
Nature index of biotechnology stocks
}

\begin{tabular}{|c|c|c|c|c|c|}
\hline $\begin{array}{l}\text { 12-Month } \\
\text { high }\end{array}$ & $\begin{array}{l}\text { 12-Month } \\
\text { low }\end{array}$ & Company & $\begin{array}{l}\text { Close } \\
\text { previous } \\
\text { month }\end{array}$ & $\begin{array}{l}\text { Close } \\
27 \text { Jan. }\end{array}$ & Change \\
\hline $23 \frac{1 / 4}{4}-1$ & $93 / 4$ & Biogen (Switzerland) & $10^{3 / 4}$ & $12^{1 / 2}$ & $+13 / 4$ \\
\hline $61 / 4$ & $15 / 8$ & Bio-Logicals (Canada) & $15 / 8$ & 2 & $+3 / 6$ \\
\hline $16 / 8$ & $71 / 4$ & Bio-Response (USA) & 10 & $11^{3 / 4}$ & $+13 / 4$ \\
\hline 19 & $10^{1 / 2}$ & Cetus (USA) & $107 / 8$ & $13^{1 / 8}$ & $+21 / 4$ \\
\hline $151 / 2$ & $61 / 2$ & Collaborative Research (USA) & $63 / 4$ & $81 / 4$ & $+1 \frac{1 / 2}{2}$ \\
\hline $39^{7 / 8}$ & 15 & Damon (USA) & $15^{3} / 8$ & $173 / 4$ & $+2 \%$ \\
\hline $341 / 4$ & $16^{3 / 8}$ & Enzo-Biochem (USA) & 25 & 23 & -2 \\
\hline $18^{7 / 8}$ & $8 \%$ & Flow General (USA) & $91 / 2$ & $83 / 4$ & $-3 / 4$ \\
\hline $493 / 4$ & $25 \%$ & Genentech (USA) & $34^{1 / 2}$ & $371 / 4$ & $+23 / 4$ \\
\hline $173 / 4$ & $7 \% / 8$ & Genetic Systems (USA) & $87 / 8$ & $83 / 8$ & $-1 / 2$ \\
\hline $231 / 4$ & $12^{1 / 2}$ & Genex (USA) & 13 & $13^{1 / 2}$ & $+1 / 2$ \\
\hline 31 & $18^{3 / 4}$ & Hybritech (USA) & $18^{3 / 4}$ & 21 & $+2 \frac{1}{4}$ \\
\hline $221 / 4$ & $107 / 8$ & Molecular Genetics (USA) & 12 & $141 / 2$ & $+21 / 2$ \\
\hline $231 / 4$ & $101 / 2$ & Monoclonal Antibodies (USA) & 12 & $12 \frac{1}{2}$ & $+1 / 2$ \\
\hline $73 \frac{1}{1} 2$ & 42 & Novo Industri A/S (Denmark) & 56 & $55^{3 / 8}$ & $-5 / 8$ \\
\hline $301 / 4$ & $13 \%$ & Pharmacia (Sweden) & $19^{3 / 8}$ & $18^{7 / 8}$ & $-1 / 2$ \\
\hline
\end{tabular}

Closing prices are for the last Friday of the month. For over-the-counter stocks, bid price is quoted; for stocks on the American and New York exchanges, the transaction price. Nature's weighted index of biotechnology stocks stood at 181 on $27 \mathrm{~J}$ anuary, compared with 175 a month earlier. Data from E.F. Hutton, Inc. 